\title{
Plasma 25-hydroxyvitamin D and not 1,25-dihydroxyvitamin D is associated with parathyroid adenoma secretion in primary hyperparathyroidism: a cross-sectional study
}

\author{
B Moosgaard ${ }^{1}$, P Vestergaard ${ }^{1}$, L Heickendorff ${ }^{2}$, F Melsen $^{3}$, P Christiansen $^{4}$ and L Mosekilde ${ }^{1}$ \\ Aarhus Bone and Mineral Research Group, Departments of ${ }^{1}$ Endocrinology and Metabolism C, ${ }^{2}$ Clinical Biochemistry, ${ }^{3}$ Histopathology and ${ }^{4}$ Surgical \\ Department L, Aarhus University Hospital, Tage-Hansensgade 2, DK 8000 Aarhus C, Denmark
}

(Correspondence should be addressed B Moosgaard, Email: bmoos@as.aaa.dk)

\begin{abstract}
Background: Primary hyperparathyroidism (PHPT) is associated with reduced plasma 25-hydroxyvitamin D (P-250HD) and usually increased plasma 1 1 ,25-dihydroxyvitamin D $\left(\mathrm{P}-1,25(\mathrm{OH})_{2} \mathrm{D}\right)$. Parathyroid tissue expresses the vitamin D receptor and it is thought that circulating $1,25(\mathrm{OH})_{2} \mathrm{D}$ participate in the regulation of parathyroid cell proliferation, differentiation and secretion.

Aim: To investigate the relations between circulating levels of $1,25(\mathrm{OH})_{2} \mathrm{D}$ and $25 \mathrm{OHD}$ respectively and parathyroid adenoma weight (AW), plasma-parathyroid hormone (P-PTH) and PTH secretion expressed as P-PTH/AW.

Design: Cross-sectional study.

Material: One hundred and seventy-one consecutive hypercalcaemic caucasian patients aged 19-87 years (median 63, 84\% females) with surgically proven parathyroid adenoma.

Results: A weak positive correlation was found between P-250HD and P-1,25(OH $)_{2} \mathrm{D}(r=0.24$, $P<0.005)$. AW depended on sex and body mass index. Following adjustment, it was correlated positively to P-PTH, calcium (Ca) and alkaline phosphatase (AP) and inversely to plasma phosphate in a multiple regression model. AW was not associated with vitamin D metabolites. Preoperative P-PTH correlated positively to plasma levels of $\mathrm{Ca}$ and $\mathrm{AP}$, but inversely to phosphate and 250HD $(P<0.001)$ levels. P-PTH was not associated with $\mathrm{P}-1,25(\mathrm{OH})_{2} \mathrm{D}$ $(P=0.65)$. The P-PTH:AW ratio correlated inversely to $\mathrm{P}-250 H D(P<0.05)$, but showed no relations to plasma levels of $\mathrm{Ca}$, phosphate or $1,25(\mathrm{OH})_{2} \mathrm{D}(P=0.22)$.

Conclusion: In this material, low levels of $250 \mathrm{HD}$ were related to higher levels of P-PTH and higher PTH:AW ratios in patients with PHPT suggesting that vitamin D deficiency increase PTH secretion activity. Neither PTH secretion nor AW was associated with circulating levels of $1,25(\mathrm{OH})_{2} \mathrm{D}$.
\end{abstract}

European Journal of Endocrinology 155 237-244

\section{Introduction}

Parathyroid hormone (PTH) stimulates the renal 25 -hydroxyvitamin D-1 $\alpha$-hydroxylase (1), whereas the enzyme activity is reduced by hypercalcaemia, hyperphosphataemia, decreased renal function and excess 1 $\alpha, 25$-dihydroxyvitamin $\mathrm{D}\left(1,25(\mathrm{OH})_{2} \mathrm{D}\right)$ (2). In consequence, plasma 1 1 2,25 -dihydroxyvitamin D $\left(\mathrm{P}-1,25(\mathrm{OH})_{2} \mathrm{D}\right)$ is usually high normal or elevated in primary hyperparathyroidism (PHPT) (3-5), although low levels have also been reported depending on available plasma 25-hydroxyvitamin D (P-250HD), renal function and the degree of hypercalcaemia $(3,4,6-8)$.

In general, $1,25(\mathrm{OH})_{2} \mathrm{D}$ regulates gene transcription through a nuclear high-affinity receptor (vitamin D receptor, (VDR)) (9) and the initiation of rapid cellular responses through a putative plasma-membrane- associated receptor (10). Parathyroid tissue expresses VDR and $1,25(\mathrm{OH})_{2} \mathrm{D}$ regulates parathyroid cell proliferation, differentiation and secretion (11) and also increases the expression of the Ca sensing receptor (CaSR) $(2,12)$. However, both VDR and CaSR expression are reduced in parathyroid adenoma (PA) cells (13-15) suggesting a partial resistance to $1,25(\mathrm{OH})_{2} \mathrm{D}$ in primary, but not in secondary hyperparathyroidism (11).

Many tissues, including parathyroid cells, express the low-density lipoprotein receptor-related protein (LRP)-2 or megalin, which in the kidney very likely mediates tubular reabsorption of the $25 \mathrm{OHD}_{3}$-vitamin $\mathrm{D}$ binding protein complex (16), in combination with a 25 -hydroxyvitamin D-1- $\alpha$-hydroxylase $(17,18)$. Theoretically, the parathyroids thereby possess the capability to produce $1,25(\mathrm{OH})_{2} \mathrm{D}$ locally from circulating $25 \mathrm{OHD}$ and 
P-250HD may participate in the regulation of parathyroid cell proliferation, differentiation and secretion. This is further corroborated by the finding of increased 25-hydroxyvitamin $\mathrm{D}_{3} 1 \alpha$-hydroxylase and reduced 25-hydroxyvitamin $\mathrm{D}_{3}$ 24-hydroxylase expression in PAs (19).

It has recently been documented that PHPT patients have reduced plasma levels of $250 \mathrm{HD}$ independent of age, sex and season (20). Furthermore, based on sporadic P-250HD measurements, it has been suggested that chronic vitamin $\mathrm{D}$ deficiency may accelerate PA growth and PTH secretion and thereby aggravate bone turnover and bone loss $(14,21,22)$.

In a cross-sectional design, we investigated possible relations between the two above-mentioned vitamin $\mathrm{D}$ metabolites $\left(\mathrm{P}-1,25(\mathrm{OH})_{2} \mathrm{D}\right.$ and $\left.\mathrm{P}-25 \mathrm{OHD}\right)$ and parathyroid adenoma weight (AW), plasma-parathyroid hormone (P-PTH) and PTH secretory activity respectively in 172 patients with surgically proven PA in order to disclose the pathophysiological importance of the two circulating metabolites for adenoma size and PTH secretion. PTH secretory activity was assessed as the ratio of P-PTH to AW taking potential confounders into account.

\section{Materials and methods}

\section{Materials}

Figure 1 depicts the study profile and Table 1 characterizes the included patients. From January 1994 to January 2003, we investigated a total of 357 consecutive caucasian patients with the suspicion of PHPT, because of hyperparathyroid hypercalcaemia. Hypercalcaemia was defined by elevated albumin adjusted plasma calcium (Ca) $(>2.52 \mathrm{mmol} / \mathrm{l})$ and hyperparathyroidism or high normal (upper one-third of reference range) of plasma

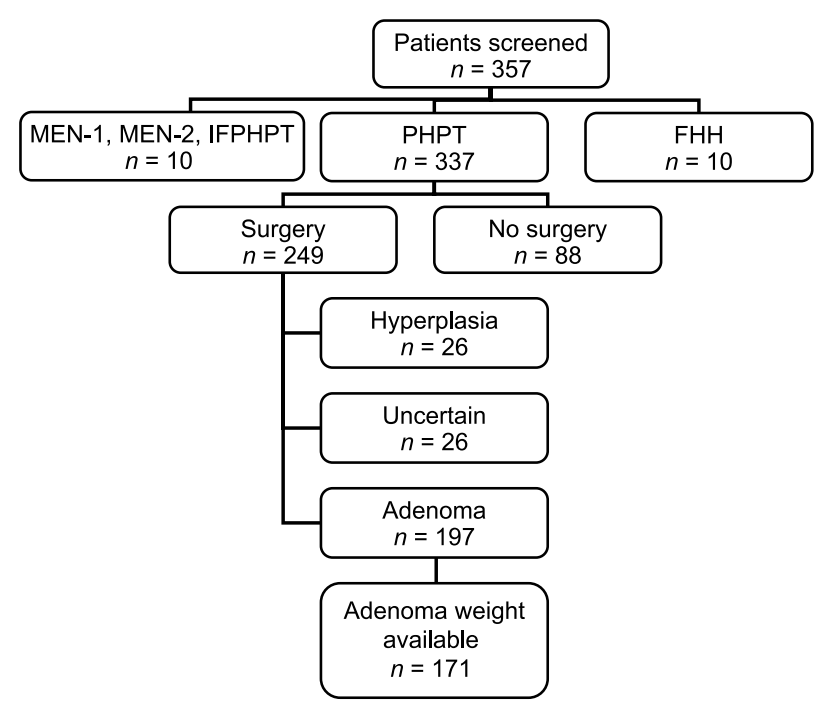

Figure 1 Study profile illustrating the selection of the final study population. intact parathyroid hormone $(\mathrm{P}-\mathrm{PTH}>5 \mathrm{pmol} / \mathrm{l})$. The upper one-third of the normal range was included, since the normal range for P-PTH depends on vitamin D status in the reference population $(23,24)$. During the screening phase, we excluded ten patients because of suspicion of familial hypocalciuric hypercalcaemia due to a $\mathrm{Ca} /$ creatinine clearance rate $<0.01$ or a clinical significant mutation in the CaSR gene. Ten were excluded because of MEN1 $(n=7)$, MEN2a $(n=1)$ or isolated familial PHPT $(n=2)$. Among the remaining 337 PHPT patients, 249 underwent neck exploration and 197 (79\%) had a PA removed. Parathyroid AW was available in 171 of the patients, all of whom were normocalcaemic postoperatively. These patients constitute the final material for the present investigation. The histological diagnosis was made from frozen section of the removed pathological parathyroid tissue. All removed parathyroid tissue was re-evaluated on paraffin-embedded sections by the same pathologist (F Melsen). The histological adenoma diagnosis was based on an enlarged gland with a confluence of dense parathyroid cells, no or sparse stromal and cytoplasmatic fat, and often a rim of normal parathyroid tissue outside the adenoma (25). Among the remainder, $26(10 \%)$ had hyperplasia and the histological classification was uncertain in $26(10 \%)$ of the patients. Double adenomas were removed in four patients. The weights of the double adenomas were added in the analysis.

We collected preoperative data as part of a standardized protocol aimed at confirming the diagnosis and assessing possible complications. The database was accepted by the Danish Data Protection Agency.

\section{Methods}

We measured PA wet weight to the nearest milligram shortly after removal using an electronic scale.

We measured plasma and urinary $\mathrm{Ca}$, albumin and creatinine by standard laboratory methods. We corrected total plasma $\mathrm{Ca}$ for individual variations in albumin by the equation,

adjusted plasma $\mathrm{Ca}(\mathrm{mmol} / \mathrm{l})$

$$
\begin{gathered}
=\text { plasma Ca total }(\mathrm{mmol} / \mathrm{l})-0.00086 \\
\times(650-\text { plasma albumin }(\mu \mathrm{mol} / \mathrm{l})) .
\end{gathered}
$$

We measured P-PTH by an IMMULITE automated analyser (Diagnostic Products Corporation, Los Angeles, CA, USA). The coefficient of variation (CV) in our lab. was less than $7 \%$. We measured P-250HD by an equilibrium RIA procedure (DiaSorin, Inc., Stillwater, MN, USA) with inter- and intraassay CV values of 13 and $10 \%$ respectively. $\mathrm{P}-1,25(\mathrm{OH})_{2} \mathrm{D}$ was measured by RIA (Nichols Institute, San Clemente, CA, USA) with inter- and intraassay CV values of 11 and $11 \%$ respectively. Cross-reaction with $250 \mathrm{HD}$ is $0.001 \%$. We measured alkaline phosphatase (AP) spectrophotometrically using an automated instrument (Hitachi 917, Roche). The total CV was less than 8\%. 
Table 1 Clinical characteristics of 171 caucasian patients with primary hyperparathyroidism (PHPT) caused by a parathyroid adenoma (PA). Biochemical values are compared with normal reference values for the laboratory.

\begin{tabular}{|c|c|c|c|c|}
\hline & \multicolumn{2}{|r|}{ PHP-patients } & \multirow[b]{2}{*}{ 95\% Reference values } & \multirow{2}{*}{$\begin{array}{c}\text { Outside } 95 \% \text { reference } \\
\text { values }(\%)\end{array}$} \\
\hline & $n$ & Median (range) or \% & & \\
\hline Age (years) & 171 & $63.0(19-87)$ & & \\
\hline Females (\%) & 171 & $83.6 \%$ & & \\
\hline Height $(\mathrm{cm})$ & 123 & $164(143-191)$ & & \\
\hline Body weight $(\mathrm{kg})$ & 134 & $70.5(42.0-155.0)$ & & \\
\hline $\operatorname{BMI}\left(\mathrm{kg} / \mathrm{m}^{2}\right)$ & 123 & $26.5(16.7-51.8)$ & & \\
\hline Vitamin D supplementation* & 171 & $11.1 \%$ & & \\
\hline Adenoma weight $(\mathrm{g}) \dagger$ & 171 & $0.75(0.038-26.5)$ & & \\
\hline $\mathrm{P}-\mathrm{Ca}$, corr. $(\mathrm{mmol} / \mathrm{l})$ & 171 & $2.82(2.53-3.73)$ & $2.20-2.52$ & 100 [i] \\
\hline \multirow{2}{*}{\multicolumn{5}{|c|}{$\mathrm{P}-25 \mathrm{OHD}(\mathrm{nmol} / \mathrm{l}) \ddagger$}} \\
\hline & & & & \\
\hline Summer (April-September) & 86 & $38(6-90)$ & $49-160$ & $72[d]$ \\
\hline Winter (October-March) & 75 & $30(4-81)$ & $12-85$ & 11 [d] \\
\hline $\mathrm{P}-1,25(\mathrm{OH}) 2 \mathrm{D}(\mathrm{pmol} / \mathrm{l}) \S$ & 150 & $120(9-250)$ & $40-160$ & $29[\mathrm{i}]$ \\
\hline P-phosphate $(\mathrm{mmol} / \mathrm{l})$ & 161 & $0.90(0.45-1.80)$ & $0.80-1.50$ & $25[\mathrm{~d}]$ \\
\hline P-alkaline phosphatase (U/I) & 160 & $213(81-1598)$ & $54-206$ & $56[i]$ \\
\hline P-creatinine $(\mu \mathrm{mol} / \mathrm{l})$ & 171 & $78(35-225)$ & $44-133$ & 5 [i] \\
\hline Pt-creatinine clearance rate $(\mathrm{ml} / \mathrm{min})$ & 146 & $81(16-200)$ & $70-140$ & 35 [d] \\
\hline $\mathrm{U}-\mathrm{Ca}(\mathrm{mmol}) / 24 \mathrm{~h}$ & 153 & $7.5(0.6-24.7)$ & $2.0-7.0$ & 56 [i] \\
\hline
\end{tabular}

[i] Increased values; [d] decreased values.

* Up to 3 months before surgery. †Four double adenomas were included. The weights of these double adenomas were added together giving one total adenoma weight (AW) in each of the four cases. fReference values are based on 187 healthy blood donors aged 41 (22-62) years and collected during summer $(n=100)$ and winter $(n=87)$ periods. §Reference values are based on 134 healthy people ( 74 blood donors and 60 perimenopausal women).

Patient $(\mathrm{Pt})$ creatinine clearance rate was calculated from the plasma creatinine and the 24-h renal excretion of creatinine. All measurements were accredited by DANAK (Skovlunde, Denmark).

The activity of the PA was estimated as the ratio of P-PTH to parathyroid AW, i.e. the P-PTH level obtained by a certain volume of PA tissue.

\section{Statistical analysis}

We expressed basic variables by their medians and ranges and assessed between group differences by the MannWhitney test. We used parametric statistics and multiple linear regressions following logarithmic transformation of data when necessary to assess relations between variables. The analysis was performed with backward stepwise estimation with a significance level for the removal of 0.05. We also used a hierarchic multiple linear regression model with preselected inclusion of either 250HD or $1,25(\mathrm{OH})_{2} \mathrm{D}$ in order to compensate for colinearity between the two vitamin D metabolites. Statistical analyses were performed with STATA version 8.2 software (StataCorp., College Station, Texas, USA).

\section{Results}

\section{Baseline characteristics}

The clinical characteristics of the 171 patients with PHPT and PA are given in Table 1 together with locally established laboratory reference values. All patients were hypercalcaemic and 85\% had elevated P-PTH compared with a normal reference population including vitamin
D-insufficient, as well as vitamin D-sufficient individuals. All had P-PTH above $5 \mathrm{pmol} / \mathrm{l}$. The PA patients had reduced $\mathrm{P}-25 \mathrm{OHD}$ compared with controls during both summer $(72 \%, P<0.001)$ and winter $(11 \%, P<0.05)$. The percentage of patients with $250 \mathrm{HD}$ below 50 and 75 $\mathrm{nmol} / \mathrm{l}$ was 79 and $96 \%$ respectively compared with $35 \%$ $(P<0.001)$ and $60 \%(P<0.001)$ of the controls. P$1,25(\mathrm{OH})_{2} \mathrm{D}$ was elevated in $29 \%(P<0.001)$ and reduced in $3 \%(P=0.74)$. Well, over half $(56 \%)$ of the patients had elevated plasma AP (P-AP). The renal Ca excretion was increased in $56 \%$ and the endogenous creatinine clearance rate was reduced in 35\%.

\section{Relation between vitamin $D$ metabolites}

$\mathrm{P}-1,25(\mathrm{OH})_{2} \mathrm{D}$ correlated positively to plasma $\ln (250 \mathrm{HD})(r=0.24, P<0.005$; Fig. 2$)$. Overall, only $6 \%$ of the variation in $\mathrm{P}-1,25(\mathrm{OH})_{2} \mathrm{D}$ could be explained by variations in $\ln (\mathrm{P}-25 \mathrm{OHD})$.

\section{Parathyroid adenoma weight and vitamin D metabolites}

Table 2 explores the influence of age, sex, body mass index (BMI) and renal function on AW. Age did not influence AW. There was a significant effect of sex with a larger number of females with small PA. High BMI was associated with higher AW. AW was not related to renal function.

Table 3 gives unadjusted and multiple adjusted relationships between AW and biochemical variables related to Ca and vitamin D metabolism. Larger adenomas were positively associated with higher plasma levels of 


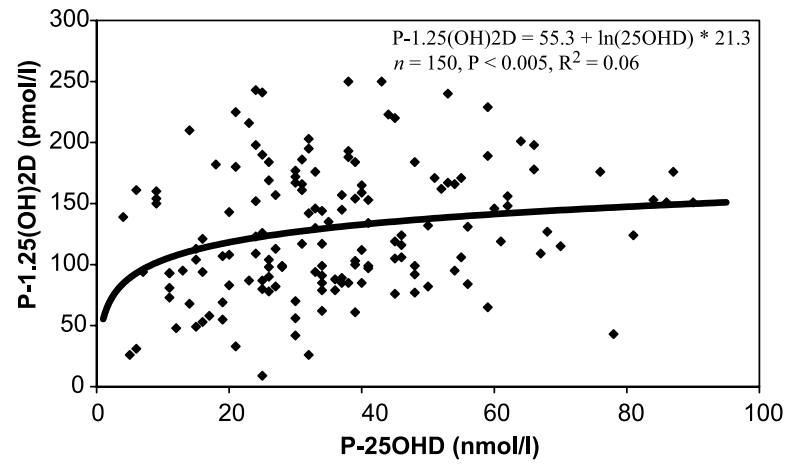

Figure 2 Relationship between plasma 25-hydroxyvitamin D (P-25OHD) and plasma 1,25-dihydroxyvitamin D ( $\mathrm{P}$ $\left.1,25(\mathrm{OH})_{2} \mathrm{D}\right)$ in 150 patients with primary hyperparathyroidism due to parathyroid adenoma.

PTH, Ca and AP and lower levels of phosphate. In the unadjusted analysis, P-250HD showed an inverse association with AW. However, when adjusted for covariates, the association became insignificant. AW was not related to plasma $1.25(\mathrm{OH})_{2} \mathrm{D}$ in any of the models used. Exclusion of three large PAs weighing 12.9, 25.5 and $26.5 \mathrm{~g}$, or exclusion of three small adenoma $(<$ $0.01 \mathrm{~g}$ ), or exclusion of four double adenomas did not change these associations (data not shown).

\section{P-PTH and vitamin D metabolites}

Table 4 gives unadjusted and multiple adjusted relationships between P-PTH and biochemical variables related to $\mathrm{Ca}$ and vitamin $\mathrm{D}$ metabolism. In the unadjusted analyses, P-PTH correlated positively to P$\mathrm{Ca}$ and P-AP and inversely to plasma phosphate and $\mathrm{P}-250 H D$. There was no significant correlation to P$1,25(\mathrm{OH})_{2} \mathrm{D}$. Adjustment for age, sex, BMI and creatinine did not change these results. In a multiple backward regression analysis including age, sex, BMI, plasma $\mathrm{Ca}$, plasma phosphate, plasma creatinine, $\mathrm{P}-25 \mathrm{OHD}$ and $\mathrm{P}-1,25(\mathrm{OH})_{2} \mathrm{D}$, P-PTH depended $(\mathrm{P}<$ $0.05)$ positively on plasma $\mathrm{Ca}$ and inversely on $\mathrm{P}-25 \mathrm{OHD}$. The equation was

$$
\begin{aligned}
\ln (\mathrm{P}-\mathrm{PTH})= & 5.71 \times \ln (\mathrm{Ca})-0.36 \times \ln (25 \mathrm{OHD}) \\
& -2.05, \mathrm{R}^{2}=0.51
\end{aligned}
$$

P-1,25(OH $)_{2} \mathrm{D}$ neither correlates to P-PTH levels in this model nor in any hierarchic multiple regression analysis with a primary inclusion of $\mathrm{P}-1,25(\mathrm{OH})_{2} \mathrm{D}$ with or without exclusion of P-250HD.

\section{Parathyroid activity and vitamin D metabolites}

Parathyroid activity was estimated as the ratio of P-PTH to AW. Table 5 gives simple and multiple adjusted relationships between parathyroid activity and various variables related to Ca and vitamin D metabolism. In the unadjusted analysis, plasma phosphate correlated positively with the P-PTH:AW ratio. No relationship was found to plasma levels of Ca or vitamin D metabolites. In the adjusted analysis also including plasma creatinine, the association with plasma phosphate became insignificant. However, in this analysis, P-250HD correlated inversely to the $\mathrm{PTH} / \mathrm{AW}$ ratio $(P<0.05)$. No relationship was found between $\mathrm{P}-1,25(\mathrm{OH})_{2} \mathrm{D}$ and $\mathrm{PTH} / \mathrm{AW}$ in any of the analyses. In a multiple backward regression analysis including age, sex, BMI, plasma Ca, plasma phosphate, plasma creatinine, P-250HD and $\mathrm{P}-1,25(\mathrm{OH})_{2} \mathrm{D}$, parathyroid activity depended $(P<0.05)$ positively on the female sex, inversely on BMI and P-250HD. The equation was

$$
\begin{aligned}
\ln (\mathrm{PTH} / \text { adenoma weight })= & 0.607 \times(\mathrm{sex}(\mathrm{females})) \\
& -0.036 \times \mathrm{BMI}-0.317 \\
& \times \ln (\mathrm{P}-25 \mathrm{OHD})+4.718, \\
& \left.\mathrm{R}^{2}=0.13\right)
\end{aligned}
$$

P-1,25(OH $)_{2} \mathrm{D}$ neither correlates to PA activity in this model nor in any hierarchic multiple regression analysis with a primary inclusion of $\mathrm{P}-1,25(\mathrm{OH})_{2} \mathrm{D}$ and in or exclusion of P-250HD. Exclusion of three large PAs weighing 12.9, 25.5 and $26.5 \mathrm{~g}$, or exclusion of three small adenoma $(<0.01 \mathrm{~g})$, or exclusion of four double adenomas did not change these associations in the multiple regression analysis (data not shown).

\section{Discussion}

\begin{tabular}{|c|c|c|c|c|}
\hline & $n$ & $\mathrm{AW}<0.745 \mathrm{~g}$ & $A W>0.745 \mathrm{~g}$ & $P$-value* \\
\hline & 171 & 85 & 86 & - \\
\hline Age (years) & 171 & $63.0(18.6-85.5)$ & $62.6(29.4-87.4)$ & $=0.46$ \\
\hline$\%$ Females & 171 & 90.5 & 77.3 & $<0.01$ \\
\hline BMI $\left(\mathrm{kg} / \mathrm{m}^{2}\right)$ & $123 t$ & $25.5(16.7-41.4)$ & $28.1(17.5-51.8)$ & $<0.01$ \\
\hline Pt-creatinine clearance rate $(\mathrm{ml} / \mathrm{min})$ & $146 \ddagger$ & $80.2(25.2-199.8)$ & $82.2(15.9-170.2)$ & $=0.38$ \\
\hline
\end{tabular}

The present cross-sectional study has shown that declining levels of $250 \mathrm{HD}$ are related to increasing

Table 2 Age, sex, BMI and renal function among patients with primary hyperparathyroidism (PHPT) stratified according to the median parathyroid adenoma weight (AW).

*The distribution of females were analysed with $\chi^{2}$ for trend. $†$ The number of available data is 66 and 57 respectively. $\ddagger$ The number of available data is 74 and 72 respectively. 
Table 3 Simple linear regression and adjusted multiple regression analysis (partial correlation coefficients) of relations between parathyroid adenoma weight $(\mathrm{AW})$ and various clinical indices of disease severity in patients with primary hyperparathyroidism (PHPT).

\begin{tabular}{|c|c|c|c|c|c|c|}
\hline \multirow[b]{2}{*}{ AW (g) (In) } & \multicolumn{2}{|c|}{ Simple linear regression } & \multirow[b]{2}{*}{$\boldsymbol{P}$} & \multicolumn{2}{|c|}{$\begin{array}{l}\text { Adjusted for age, sex, BMI and } \\
\text { P-creatinine }\end{array}$} & \multirow[b]{2}{*}{$\boldsymbol{P}$} \\
\hline & $n$ & $r$ & & $n$ & $r_{\mathrm{p}}$ & \\
\hline P-PTH (pmol/l) & 171 & 0.49 & $<0.001$ & 123 & 0.41 & $<0.001$ \\
\hline $\mathrm{P}-\mathrm{Ca}(\mathrm{mmol} / \mathrm{l})$ & 171 & 0.48 & $<0.001$ & 123 & 0.40 & $<0.001$ \\
\hline P-phosphate $(\mathrm{mmol} / \mathrm{l})$ & 161 & -0.35 & $<0.001$ & 116 & -0.22 & $<0.05$ \\
\hline P-25OHD (mmol/l) & 161 & -0.17 & $<0.05$ & 119 & -0.08 & $<0.40$ \\
\hline $\mathrm{P}-1,25(\mathrm{OH})_{2} \mathrm{D}(\mathrm{pmol} / \mathrm{l})$ & 150 & 0.01 & $<0.91$ & 111 & 0.14 & $<0.13$ \\
\hline P-AP (U/I) & 161 & 0.27 & $<0.001$ & 116 & 0.21 & $<0.05$ \\
\hline
\end{tabular}

levels of P-PTH and higher PTH secretion activity (PTH:AW ratio) in patients with PHPT caused by PA. There was no relation between P-250HD and AW after adjustment for age, sex, BMI and renal function. This suggests that vitamin D deficiency mainly increases PTH secretion activity in existing adenomas. Our findings could not reproduce an effect of vitamin D insufficiency on adenoma growth previously reported based on point estimates of P-25OHD (14). Neither PTH secretion nor AW was associated with circulating levels of $1,25(\mathrm{OH})_{2} \mathrm{D}$.

The parathyroid glands express VDR and $1,25(\mathrm{OH})_{2} \mathrm{D}$ is thought to inhibit parathyroid tissue growth and secretion $(11,18)$ in part by increasing the expression of the CaSR $(2,12)$. The inhibitory effect of $1,25(\mathrm{OH})_{2} \mathrm{D}$ on PTH secretion is well established in patients with endstage renal failure and secondary hyperparathyroidism (26). However, the present study has failed to show any relationship between $\mathrm{P}-1,25(\mathrm{OH})_{2} \mathrm{D}$ and adenoma size or secretion in PHPT patients.

One explanation for the lack of effect of $1,25(\mathrm{OH})_{2} \mathrm{D}$ on PTH secretion in our study could be that the expression of VDR and CaSR is reduced in PA cells (13-15) in combination with the sparse increase in P-1,25(OH)2D observed in PHPT. The possible partial resistance of PA cells to $1,25(\mathrm{OH})_{2} \mathrm{D}$ is supported by in vitro studies showing that $1,25(\mathrm{OH})_{2} \mathrm{D}$ inhibits cell proliferation and apoptosis in secondary but not in PHPT, suggesting that $1,25(\mathrm{OH})_{2} \mathrm{D}$ may reduce gland mass in the former but not in the latter condition (11). However, in a recent case report, Kinoshita et al. (27) showed that ectopic $1,25(\mathrm{OH})_{2} \mathrm{D}$ production in sarcoidosis may reduce P-PTH in a patient with PHPT.

Another explanation could be that a balanced negative feedback system exists between P-PTH and $1,25(\mathrm{OH})_{2} \mathrm{D}$ levels. In this system, any increase in P-PTH will enhance renal $1,25(\mathrm{OH})_{2} \mathrm{D}$ production, which again will decrease PTH secretion until a new steady-state situation is reached. However, in such a system, a residual increase in P-PTH and $1,25(\mathrm{OH})_{2} \mathrm{D}$ would be necessary in order to maintain the new balance. Hence, in a cross-sectional study, a positive relationship should be observed between P-PTH and $\mathrm{P}-1,25(\mathrm{OH})_{2} \mathrm{D}$. However, any other factor decreasing the response of the renal $1 \alpha$-hydroxylase to excess PTH, i.e. hypercalcaemia, reduced renal function and excess $1,25(\mathrm{OH})_{2} \mathrm{D}$, as found in PHPT, would tend to mitigate the effect of PTH on $\mathrm{P}-1,25(\mathrm{OH})_{2} \mathrm{D}$ and thereby create an inverse relationship between PTH and $1,25(\mathrm{OH})_{2} \mathrm{D}$. The outlined homeostatic mechanisms may in combination explain the lack of association between plasma levels of $1,25(\mathrm{OH})_{2} \mathrm{D}$ and PTH.

The most likely explanation for the observed inverse relationship between P-25OHD and P-PTH and PTH/AW ratio is that the parathyroid cells - like many other normal cells participating in Ca homeostasis (keratinocytes, placenta and bone cells) and several malignant cells (colon, prostate, breast and lung) - express a $1 \alpha-$ hydroxylase that intracellularly converts $250 \mathrm{HD}$ to $1,25(\mathrm{OH})_{2} \mathrm{D}(17,18,28)$. Parathyroid cells, like many other tissues, also express the low density LRP-2 or megalin (17). In the proximal tubulus of the kidney, this receptor apparently mediates the reabsorption of the

Table 4 Simple linear regression and adjusted multiple regression analysis (partial correlation coefficients) of relations between plasmaparathyroid hormone (P-PTH) and various indices of calcium (Ca) and vitamin D metabolism in primary hyperparathyroidism (PHPT).

\begin{tabular}{|c|c|c|c|c|c|c|}
\hline \multirow[b]{2}{*}{ P-PTH (pmol/l) (In) } & \multicolumn{2}{|c|}{ Simple linear regression } & \multirow[b]{2}{*}{$\boldsymbol{P}$} & \multicolumn{2}{|c|}{$\begin{array}{l}\text { Adjusted for age, sex, BMI and } \\
\text { creatinine }\end{array}$} & \multirow[b]{2}{*}{$P$} \\
\hline & $n$ & $r$ & & $n$ & $r_{\mathrm{p}}$ & \\
\hline $\mathrm{P}-\mathrm{Ca}(\mathrm{mmol} / \mathrm{l})$ & 171 & 0.62 & $<0.001$ & 123 & 0.59 & $<0.001$ \\
\hline P-phosphate $(\mathrm{mmol} / \mathrm{l})$ & 161 & -0.24 & $<0.005$ & 116 & -0.23 & $<0.05$ \\
\hline $\mathrm{P}-25 \mathrm{OHD}(\mathrm{mmol} / \mathrm{l})$ & 161 & -0.31 & $<0.001$ & 119 & -0.40 & $<0.001$ \\
\hline $\mathrm{P}-1,25(\mathrm{OH})_{2} \mathrm{D}(\mathrm{pmol} / \mathrm{l})$ & 150 & -0.14 & 0.10 & 111 & 0.05 & 0.65 \\
\hline P-AP (U/I) & 160 & 0.53 & $<0.001$ & 116 & 0.51 & $<0.001$ \\
\hline
\end{tabular}


Table 5 Simple linear regression and adjusted multiple regression analysis (partial correlation coefficients) of relations between plasma-parathyroid hormone (P-PTH)/parathyroid adenoma weight (AW) and various indices of calcium (Ca) and vitamin D metabolism in primary hyperparathyroidism (PHPT).

\begin{tabular}{|c|c|c|c|c|c|c|}
\hline \multirow[b]{2}{*}{ PTH/AW (In) } & \multicolumn{2}{|c|}{ Simple linear regression } & \multirow[b]{2}{*}{$P$} & \multicolumn{2}{|c|}{$\begin{array}{l}\text { Adjusted for age, sex and } \\
\text { BMI, creatinine }\end{array}$} & \multirow[b]{2}{*}{$\boldsymbol{P}$} \\
\hline & $n$ & $r$ & & $n$ & $r_{\mathrm{p}}$ & \\
\hline $\mathrm{P}-\mathrm{Ca}(\mathrm{mmol} / \mathrm{l})$ & 171 & -0.06 & 0.43 & 123 & -0.01 & 0.84 \\
\hline P-phosphate $(\mathrm{mmol} / \mathrm{l})$ & 161 & 0.20 & $<0.01$ & 116 & 0.07 & 0.44 \\
\hline P-25OHD (mmol/l) & 161 & -0.04 & 0.64 & 119 & -0.19 & $<0.05$ \\
\hline $\mathrm{P}-1,25(\mathrm{OH})_{2} \mathrm{D}(\mathrm{pmol} / \mathrm{l})$ & 150 & -0.11 & 0.17 & 111 & -0.12 & 0.22 \\
\hline
\end{tabular}

filtered $25 \mathrm{OHD}_{3}$-vitamin $\mathrm{D}$ binding protein complex (16). In the parathyroids, a similar effect would enhance the cellular uptake of circulating 250HD. The increased 25-hydroxyvitamin $\mathrm{D}_{3}-1 \alpha$-hydroxylase and the reduced 25-hydroxyvitamin $\mathrm{D}_{3}$ 24-hydroxylase expressions observed in PAs may further enhance the intracellular production of $1,25(\mathrm{OH})_{2} \mathrm{D}$ from $25 \mathrm{OHD}$ (19). Hence, in PHPT even decreased circulating levels of 250HD (20) may provide an adequate amount of substrate for a local production of $1,25(\mathrm{OH})_{2} \mathrm{D}$ that can overcome the partial resistance to $1,25(\mathrm{OH})_{2} \mathrm{D}$ described above (13-15). The large difference in molar concentrations between $250 \mathrm{OD}$ and $1,25(\mathrm{OH})_{2} \mathrm{D}(1000 / 1)$ further supports such a mechanism. A local tissue production of $1,25(\mathrm{OH})_{2} \mathrm{D}$ from 250HD also explains why the development of osteomalacia (29), proximal myopathy $(30,31)$ and secondary hyperparathyroidism among the elderly $(32,33)$ depends on circulating P-250HD levels.

The observed inverse relationship between P-25OHD and adenoma in the univariate linear regression is in accordance with the results reported by Rao et al. (14). However, after adjustment for age, sex and BMI, there was no significant relation between 250HD and AW. This may be explained in several ways. P-250HD is a point estimate and may not reflect individual average vitamin D status during adenoma growth. Furthermore, the observed positive effects of BMI on adenoma size, which is in accordance with a recent metaanalysis (34) showing that body weight and BMI are increased by 0.3 s.D. $(95 \%$ CI 0.19-0.40) in PHPT compared with normocalcaemic controls, may interact. At present, it is unknown whether PHPT leads to increased body weight through stimulation of lipogenesis (35) or obesity facilitates the development of hyperparathyroidism through deposition and catabolism of vitamin D metabolites in the adipose tissue (36-38). The finding that the increase in body weight appears to antedate the development of hypercalcaemia favours the last mechanism (39). In both situations, adiposity and adenoma development may build up over time inducing a positive relationship between the variables in a cross-sectional study.

Our study supports the concept that treatment with vitamin D may have some benefits in the preoperative management of PHPT patients and, perhaps in combination with an antiresorptive agent, may be valuable as long-term treatment in unoperated patients.
However, large-scale randomized trials are warranted to assess possible benefits and risks of such a treatment.

The higher occurrence of small adenomas among females may be explained by a higher diagnostic awareness of osteoporosis and disturbances in $\mathrm{Ca}$ metabolism in this sex compared with males leading to an earlier detection of disease. However, the exclusion of small adenomas did not change results.

The usually accepted suppression of the remaining normal parathyroid glands in PHPT caused by PAs support the concept that the P-PTH:AW ratio reflects the PTH secretion activity of the adenoma. However, this ratio have not been reported or evaluated before.

\section{Strengths and limitations to study}

The main strengths of our study are its large number of consecutively admitted patients, which support the external validity of the study and the uniform protocol for data collection.

In this study, we have used PTH:AW ratio as an estimate of parathyroid activity. To our knowledge, this ratio has not been used before in similar analyses. However, the ratio has been used and reported in another context (40).

The main weakness of the study is the cross-sectional design, which impede causal interpretations. Hence, the study cannot reveal whether parathyroid function has influenced measured variables or the variables have influenced PA function and size. In particular, it cannot be concluded that plasma levels of $250 \mathrm{HD}$ influence P-PTH or parathyroid activity (PTH/AW). It may be that a high secretion of PTH and hypercalcaemia in some way reduces $\mathrm{P}-25 \mathrm{OHD}$ (20). However, our interpretation of the study is in accordance with two studies showing that treatment with vitamin D reduces P-PTH in patients with PHPT without raising plasma Ca levels $(41,42)$.

In conclusion, this study showed that in PHPT plasma levels of $1,25-(\mathrm{OH})_{2} \mathrm{D}$ correlates positively to P-250HD. Furthermore, decreased levels of P-250HD are related to increased levels of P-PTH and higher PTH:AW ratios suggesting that vitamin D deficiency increase PTH secretion activity without demonstrable effect on adenoma growth. Neither PTH secretion nor AW was associated with circulating levels of $1,25(\mathrm{OH})_{2} \mathrm{D}$. 


\section{References}

1 Fraser DR \& Kodicek E. Unique biosynthesis by kidney of a biological active vitamin D metabolite. Nature 1970228 764-766.

2 Brown AJ, Dusso A \& Slatopolsky E. Vitamin D. American Journal of Physiology 1999277 F157-F175.

3 Lalor BC, Mawer EB, Davies M, Lumb GA, Hunt L \& Adams PH. Determinants of the serum concentration of 1,25-dihydroxyvitamin D in primary hyperparathyroidism. Clinical Science 198976 81-86.

4 Mosekilde L, Charles P \& Lindegreen P. Determinants for serum 1,25-dihydroxycholecalciferol in primary hyperparathyroidism. Bone and Mineral $19895279-290$.

5 Thakker RV, Fraher LJ, Adami S, Karmali R \& O'Riordan JL. Circulating concentrations of 1,25-dihydroxyvitamin D3 in patients with primary hyperparathyroidism. Bone and Mineral 19861 137-144.

6 Frølich A, Storm T \& Thode J. Does the plasma concentration of 25-hydroxyvitamin $\mathrm{D}$ determine the level of 1,25-dihydroxyvitamin D in primary hyperparathyroidism. Mineral and Electrolyte Metabolism 199622 203-206.

7 Wortsman J, Haddad JG, Posillico JT \& Brown EM. Primary hyperparathyroidism with low serum 1,25-dihydroxyvitamin D levels. Journal of Clinical Endocrinology and Metabolism 198662 1305-1308.

8 LoCascio V, Adami S, Galvanini G, Ferrari M, Cominacini L \& Tartarotti D. Substrate-product of 1-hydroxylase activity in primary hyperparathyroidism. New England Journal of Medicine $19853131123-1125$.

9 Norman AW, Bishop JE, Bula CM, Olivera CJ, Mizwicki MT, Zanello LP, Ishida H \& Okamura WH. Molecular tools for study of genomic and rapid signal transduction responses initiated by 1 alpha,25(OH)(2)-vitamin D(3). Steroids $200267457-466$.

10 Huhtakangas JA, Olivera CJ, Bishop JE, Zanello LP \& Norman AW. The vitamin D receptor is present in caveolae-enriched plasma membranes and binds 1 alpha,25(OH)2-vitamin D3 in vivo and in vitro. Molecular Endocrinology 200418 2660-2671.

11 Canalejo A, Almaden Y, Torregrosa V, Gomez-Villamandos JC, Ramos B, Campistol JM, Felsenfeld AJ \& Rodriguez M. The in vitro effect of calcitriol on parathyroid cell proliferation and apoptosis. Journal of the American Society of Nephrology 200011 1865-1872.

12 Brown AJ, Zhong M, Finch J, Ritter C, McCracken R, Morrissey J \& Slatopolsky E. Rat calcium-sensing receptor is regulated by vitamin D but not by calcium. American Journal of Physiology 1996270 F454-F460.

13 Carling T, Rastad J, Szabo E, Westin G \& Akerstrom G. Reduced parathyroid vitamin $D$ receptor messenger ribonucleic acid levels in primary and secondary hyperparathyroidism. Journal of Clinical Endocrinology and metabolism 200085 2000-2003.

14 Rao DS, Honasoge M, Divine GW, Phillips ER, Lee MW, Ansari MR, Talpos GB \& Parfitt AM. Effect of vitamin D nutrition on parathyroid adenoma weight: pathogenetic and clinical implications. Journal of Clinical Endocrinology and Metabolism $2000 \mathbf{8 5}$ 1054-1058.

15 Sudhaker RD, Han ZH, Phillips ER, Palnitkar S \& Parfitt AM. Reduced vitamin D receptor expression in parathyroid adenomas: implications for pathogenesis. Clinical Endocrinology (Oxf) 2000 53 373-381.

16 Nykjaer A, Dragun D, Walther D, Vorum H, Jacobsen C, Herz J, Melsen F, Christensen EI \& Willnow TE. An endocytic pathway essential for renal uptake and activation of the steroid 25-(OH) vitamin D3. Cell 199996 507-515.

17 Lundgren S, Carling T, Hjalm G, Juhlin C, Rastad J, Pihlgren U, Rask L, Akerstrom G \& Hellman P. Tissue distribution of human gp330/megalin, a putative $\mathrm{Ca}(2+)$-sensing protein. Journal of Histochemistry and Cytochemistry 199745 383-392.

18 Segersten U, Correa P, Hewison M, Hellman P, Dralle H, Carling T, Akerstrom G \& Westin G. 25-hydroxyvitamin D(3)-1alphahydroxylase expression in normal and pathological parathyroid glands. Journal of Clinical Endocrinology and Metabolism 200287 2967-2972.
19 Correa P, Segersten U, Hellman P, Akerstrom G \& Westin G. Increased 25-hydroxyvitamin D3 1alpha-hydroxylase and reduced 25-hydroxyvitamin D3 24-hydroxylase expression in parathyroid tumors-new prospects for treatment of hyperparathyroidism with vitamin D. Journal of Clinical Endocrinology and Metabolism $2002 \mathbf{8 7} 5826-5829$.

20 Moosgaard B, Vestergaard P, Heickendorff L, Melsen F, Christiansen P \& Mosekilde L. Vitamin D status, seasonal variations, parathyroid adenoma weight and bone mineral density in primary hyperparathyroidism. Clinical Endocrinology (Oxf) 200563 506-513.

21 Lumb GA \& Stanbury SW. Parathyroid function in human vitamin $\mathrm{D}$ deficiency and vitamin D deficiency in primary hyperparathyroidism. American Journal of Medicine 197456 833-839.

22 Silverberg SJ, Shane E, Dempster DW \& Bilezikian JP. The effects of vitamin D insufficiency in patients with primary hyperparathyroidism. American Journal of Medicine 1999107 561-567.

23 Souberbielle JC, Cormier C, Kindermans C, Gao P, Cantor T, Forette F \& Baulieu EE. Vitamin D status and redefining serum parathyroid hormone reference range in the elderly. Journal of Clinical Endocrinology and Metabolism 200186 3086-3090.

24 Souberbielle JC, Lawson-Body E, Hammadi B, Sarfati E, Kahan A \& Cormier $\mathrm{C}$. The use in clinical practice of parathyroid hormone normative values established in vitamin D-sufficient subjects. Journal of Clinical Endocrinology and Metabolism 200388 35013504.

25 Livolsi VA. Parathyroids, morphology and pathology. In The Parathyroids. Basic and Clinical Concepts, pp 1-15. Eds J Bilezikian, R Marcus \& MA Levine. California: Academic Press, 2001.

26 Elder G. Pathophysiology and recent advances in the management of renal osteodystrophy. Journal of Bone and Mineral Research 2002 17 2094-2105.

27 Kinoshita Y, Taguchi M, Takeshita A, Miura D, Tomikawa S \& Takeuchi Y. 1,25-dihydroxyvitamin d suppresses circulating levels of parathyroid hormone in a patient with primary hyperparathyroidism and coexistent sarcoidosis. Journal of Clinical Endocrinology and Metabolism $2005906727-6731$.

28 Holick MF. Vitamin D: importance in the prevention of cancers, type 1 diabetes, heart disease, and osteoporosis. American Journal of Clinical Nutrition $200479362-371$.

29 Parfitt AM. Osteomalacia and related disorders. In Metabolic Bone Diseases and Clinically Related Disorders, pp 327-386. Eds LV Avioli \& SM Krane. San Diego: Academic Press, 1998.

30 Glerup H. Investigation on the role of vitamin D in muscle function - A study of muscle function in vitamin D deficient humans and effect of treatment with vitamin D. 1999. Aarhus University, Aarhus, Denmark. Ref Type: Report.

31 Glerup H, Mikkelsen K, Poulsen L, Hass E, Overbeck S, Andersen H, Charles P \& Eriksen EF. Hypovitaminosis D myopathy without biochemical signs of osteomalacic involvement. Calcified Tissue International $2000 \mathbf{6 6} 419-424$.

32 Lips P, Wiersinga A, van Ginkel FC, Jongen MJ, Netelenbos JC, Hackeng WH, Delmas PD \& van der Vijgh WJ. The effect of vitamin D supplementation on vitamin D status and parathyroid function in elderly subjects. Journal of Clinical Endocrinology and Metabolism $198867644-650$

33 Mosekilde L. Vitamin D and the elderly. Clinical Endocrinology (Oxf) 200562 265-281.

34 Bolland MJ, Grey AB, Gamble GD \& Reid IR. Association between primary hyperparathyroidism and increased body weight: a metaanalysis. Journal of Clinical Endocrinology and Metabolism 200590 $1525-1530$.

35 McCarty MF \& Thomas CA. PTH excess may promote weight gain by impeding catecholamine-induced lipolysis-implications for the impact of calcium, vitamin D, and alcohol on body weight. Medical Hypotheses 200361 535-542.

36 Bolland MJ, Grey AB \& Ames RW. Fat mass is an important predictor of parathyroid hormone levels in postmenopausal women. Bone 200638 317-321.

37 Parikh SJ, Edelman M, Uwaifo GI, Freedman RJ, Semega-Janneh M, Reynolds J \& Yanovski JA. The relationship between obesity and 
serum 1,25-dihydroxy vitamin D concentrations in healthy adults. Journal of Clinical Endocrinology and Metabolism $2004 \mathbf{8 9}$ 1196-1199.

38 Snijder MB, van Dam RM, Visser M, Deeg DJ, Dekker JM, Bouter LM, Seidell JC \& Lips P. Adiposity in relation to vitamin D status and parathyroid hormone levels: a population-based study in older men and women. Journal of Clinical Endocrinology and Metabolism $2005904119-4123$.

39 Grey A \& Reid I. Body weight and bone mineral density in hyperparathyroidism. Annals of Internal Medicine 1995123732.

40 Bergenfelz A, Lindblom P, Lindergard B, Valdemarsson S \& Westerdahl J. Preoperative normal level of parathyroid hormone signifies an early and mild form of primary hyperparathyroidism. World Journal of Surgery 200327 481-485.
41 Grey A, Lucas J, Horne A, Gamble G, Davidson JS \& Reid IR Vitamin D repletion in patients with primary hyperparathyroidism and coexistent vitamin D insufficiency. Journal of Clinical Endocrinology and Metabolism 200590 2122-2126.

42 Kantorovich V, Gacad MA, Seeger LL \& Adams JS. Bone mineral density increases with vitamin D repletion in patients with coexistent vitamin D insufficiency and primary hyperparathyroidism. Journal of Clinical Endocrinology and Metabolism $2000 \mathbf{8 5}$ 3541-3543.

Received 07 March 2006

Accepted 28 April 2006 